\title{
The color of a Dalmatian's spots: Linkage evidence to support the
} TYRPI gene

\author{
Edward J Cargill ${ }^{1}$, Thomas R Famula ${ }^{2}$, Robert D Schnabel ${ }^{3}$, George M Strain ${ }^{4}$ \\ and Keith E Murphy*1
}

\begin{abstract}
Address: ${ }^{1}$ Department of Pathobiology, College of Veterinary Medicine, Texas A\&M University, College Station, TX 77843 USA, ${ }^{2}$ Department of Animal Science, University of California-Davis, Davis, CA 95616 USA, ${ }^{3}$ Department of Animal Science, University of Missouri, Columbia, MO 65211 USA and ${ }^{4}$ Department of Comparative Biomedical Sciences, School of Veterinary Medicine, Louisiana State University, Baton Rouge, LA 70803 USA

Email: Edward J Cargill - ejcargill@tamu.edu; Thomas R Famula - trfamula@ucdavis.edu; Robert D Schnabel - schnabelr@missouri.edu; George M Strain - strain@lsu.edu; Keith E Murphy* - kmurphy@cvm.tamu.edu

* Corresponding author
\end{abstract}

Published: 26 July 2005

BMC Veterinary Research 2005, I:I doi:10.1/86/1746-6I48-I-I
Received: 24 June 2005

Accepted: 26 July 2005

This article is available from: http://www.biomedcentral.com/l746-6/48/I/I

(C) 2005 Cargill et al; licensee BioMed Central Ltd.

This is an Open Access article distributed under the terms of the Creative Commons Attribution License (http://creativecommons.org/licenses/by/2.0), which permits unrestricted use, distribution, and reproduction in any medium, provided the original work is properly cited.

\begin{abstract}
Background: The distinctive coat pattern of a Dalmatian is the result of the interaction of several loci. While the encoded function of these genes is not fully understood, it is known the Piebald, Ticking, and Flecking loci interact to produce the Dalmatian's classic pigmented spots on a white background. The color of the pigmented spots in purebred Dalmatians can either be black or liver, but the locus responsible for color determination is unknown. Studies have been conducted to determine the underlying genes involved in coat color determination in the dog, e.g., in the Labrador Retriever, but none to date have addressed black versus liver in the Dalmatian.

Results: A genome scan was conducted in a multi-generational kindred of Dalmatians segregating black and liver spot color. Linkage analysis was performed using a total of II3 polymorphic microsatellite markers from the kindred. Linkage was found between spot color and a single microsatellite marker, $\mathrm{FH} 23 \mathrm{I} 9$ (LOD = 12.5) on chromosome II.

Conclusion: The TYRPI (Brown) locus is located at position 50.I Mb on chromosome II, which is approximately $0.4 \mathrm{Mb}$ from marker FH23 19. Given the recent characterization of TYRPI genetic variations in the dog and the linkage evidence reported here, TYRPI is likely responsible for the spot color variation of black versus liver seen in the Dalmatian.
\end{abstract}

\section{Background}

The distinctive coat pattern of a Dalmatian is the result of the interaction of several genes. Specifically, it is known the extreme piebald allele of the Piebald locus, in conjunction with the ticked allele of the Ticking locus, and nonflecked allele of the Flecking locus, produces pigmented spots on a white background [1]. The color of the pigmented spots in registered Dalmatians is black or liver [2], but the locus responsible for the color variation has not been identified in the Dalmatian. Other colors are rare, but can be found [3].

Several classic pigmentation loci, such as Agouti, Extension, and Brown, have been characterized at the molecular level. The Brown locus describes tyrosinase related protein 1 (Tyrp1), which controls the production of eumelanin in 


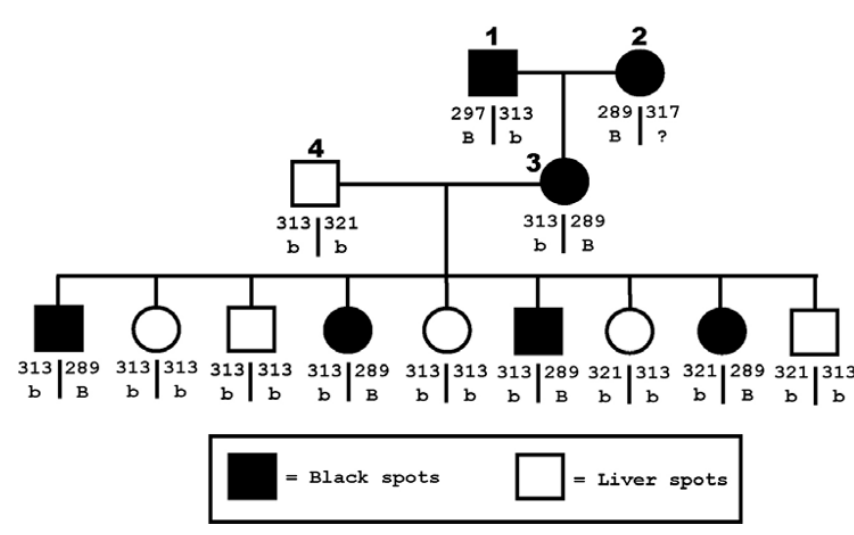

Figure I

Subset family of Dalmatians segregating black and liver spots. Marker $\mathrm{FH} 23 \mathrm{I} 9$ genotypes (allele sizes ranging from 289 bp to $32 \mathrm{l} \mathrm{bp)}$ and Brown locus alleles ( $B=$ wild type; $b=$ brown) for a subset family of Dalmatians segregating black and liver spot colors.

melanocytes [4]. In the dog, the dominant wild-type allele results in black eumelanin while the recessive brown allele results in brown eumelanin [1]. The Extension locus has been found to be the melanocortin 1 receptor (Mc1r) protein [5], which has an epistatic relationship with the Agouti locus [1]. The epistatic relationship between Agouti and Extension acts as a switch for melanocytes to produce either phaeomelanin or eumelanin, with certain alleles resulting in a red or reddish-brown color [6].

All Dalmatians are homozygous for the Piebald, Ticking, and Flecking loci (or they would not display the classic spotting pattern) complicating characterization of these loci through standard techniques, such as linkage analysis, since there is not a segregating phenotype to detect. However, black and liver spot color is a detectable phenotype that segregates in Mendelian fashion. The objective of this study was to utilize a previously described multigenerational kindred of Dalmatians [7] to conduct a genome scan and perform linkage analysis to detect linkage between spot color and a microsatellite marker. Detection of linkage will provide insight as to which locus may be responsible for black versus liver in the Dalmatian.

\section{Results}

Twopoint linkage analysis for spot color was performed using SOLAR v2.1.4 [14] and 113 polymorphic markers from the Dalmatian kindred. Marker FH2319 resulted in a statistically significant LOD score of 12.5 [8,9]. FH2319 was previously mapped to chromosome 11 at position $49.7 \mathrm{Mb}$ [10]. None of the remaining 112 markers resulted in a LOD score above the standard significance threshold of 3, including four additional polymorphic markers on CFA11. The spot color and corresponding genotypes for a subset of the kindred are shown in Figure 1.

\section{Discussion}

A genome scan was performed on a multi-generational kindred of Dalmatians, previously analyzed for heritability and segregation of deafness [7]. Spot color has been shown to not be associated with deafness in the Dalmatian [7]. Twopoint linkage analysis using SOLAR produced a LOD score of 12.5 for marker FH2319 on chromosome 11. Based on the canine genome map [10], the TYRP1 (Brown) locus is at position $50.1 \mathrm{Mb}$, which is approximately $0.4 \mathrm{Mb}$ from $\mathrm{FH} 2319$. Given the recent characterization of TYRP1 genetic variations in the dog [11] and the linkage evidence reported here, TYRP1 is likely responsible for the spot color variation of black versus liver seen in the Dalmatian.

Included in Figure 1 are suspected alleles of the Brown locus for the depicted dogs. Dog 3 is heterozygous for the dominant $B$ allele of the Brown locus (producing black spots) while dog 4 is homozygous for the recessive $b$ allele of the Brown locus (producing liver spots). Progeny of dogs 3 and 4 reveal marker FH2319 allele 289, in this family, is linked with the $B$ allele of the Brown locus. Additional alleles of marker FH2319 were also linked with the $B$ allele in the Dalmatian kindred (data not shown). Due to this fact, linkage alone is not enough to establish if a dog with an unknown Brown locus genotype (such as dog 2 in Figure 1) is homozygous or heterozygous for the dominant allele.

A recent study [11] examined genetic variations in the TYRP1 and MC1R loci in numerous dog breeds to determine the effect of the variations on black and brown pigmentation. While this work characterized the associations of specific mutations found in these genes with the pigmentation phenotypes examined, only one Dalmatian (with black spots) was included. Based on examination of the kindred reported here, the TYRP1 gene should be further characterized in the Dalmatian to determine the specific genetic variations associated with the dominant and recessive alleles of the Brown locus.

\section{Conclusion}

Statistically significant linkage was found between marker FH2319 and spot color in a kindred of Dalmatians. FH2319 is $0.4 \mathrm{Mb}$ from the TYRP1 locus, supporting evidence that its gene product is responsible for the black or liver color of a Dalmatian's spots. Further characterization of TYRP1 in the Dalmatian is warranted to determine the specific genetic variations causative for color variation. 


\section{Methods \\ Spot color}

Spot color was recorded from the Dalmatian kindred as previously described [7]. There were a total of 139 dogs with black spots ( 61 males, 78 females) and 60 with liver spots (26 males, 34 females). For the purpose of linkage analysis, spot color was coded as a binary trait with ' 0 ' for black and ' 1 ' for liver.

\section{DNA samples}

Genomic DNA was isolated from 117 dogs (54 males, 63 females) of the Dalmatian kindred reported [7]. The remaining 149 dogs of the kindred were unavailable for collection of a DNA sample. The PUREGENE DNA Isolation Kit (Gentra Systems, Minneapolis, MN, USA) was used to extract genomic DNA from either whole blood or buccal swabs according to the manufacturer's specifications.

\section{Microsatellite markers}

Microsatellite markers were amplified and resolved in multiplexed sets as described [12]. A linkage map of the markers based on the Dalmatian kindred was previously described [13]. Out of 172 total markers analyzed, 113 were polymorphic in the assembled Dalmatian kindred.

\section{Linkage analysis}

Twopoint linkage analysis was performed using the program SOLAR v2.1.4 [14] according to the developers' instructions.

\section{Authors' contributions}

EJC participated in design of the study, collected samples, performed the genome scan and linkage analysis, and drafted the manuscript. TRF was involved with the linkage analysis and review of the manuscript. RDS was involved with the linkage analysis and review of the manuscript. GMS was involved with collection of samples and review of the manuscript. KEM conceived of the study, participated in its design and coordination, and review of the manuscript.

\section{Acknowledgements}

The authors would like to acknowledge the commitment of the Dalmatian Club of America, breeders and their veterinarians who contributed samples to the project. This work was supported by the American Kennel Club Canine Health Foundation grants Number 1870 and Number 2264. E.J.C. was supported by a National Institutes of Health (National Institute on Deafness and other Communication Disorders) Individual National Research Service Award predoctoral fellowship (IF3 IDC05297).

\section{References}

I. Sponenberg DP, Rothschild MF: Genetics of coat colour and hair texture. In The genetics of the dog Edited by: Ruvinsky A, Sampson J. CABI Publishing, New York, NY; 2001:6I-85.

2. The Dalmatian Club of America [http://www.thedca.org]
3. Brooksbank S, MacMillan S, Wymore S: The Dalmatian standard. In The official book of the Dalmatian Edited by: Brooksbank S, MacMillan S, Wymore S. TFH Publications, Neptune, NJ; I997: I23-I72.

4. Jackson IJ: Molecular and developmental genetics of mouse coat colour. Ann Rev Gen 1994, 28:189-217.

5. Newton JM, Wilkie AL, Lin H, Jordan SA, Metallinos DL, Holmes NG, Jackson IJ, Barsh GS: Melanocortin I receptor variation in the domestic dog. Mam Gen 2000, I I :24-30.

6. Berryere TG, Kerns JA, Barsh GS, Schmutz SM: Association of an Agouti allele with fawn or sable coat color in domestic dogs. Mam Gen 2005, 16:262-272.

7. Cargill EJ, Famula TR, Strain GM, Murphy KE: Heritability and segregation analysis of deafness in U.S. Dalmatians. Genetics 2004, 166:1385-1393.

8. Lander E, Kruglyak L: Genetic dissection of complex traits: Guidelines for interpreting and reporting linkage results. Nat Gen 1995, I I:24 I-247.

9. Gordon D, Corwin MB, Mellersh CS, Ostrander EA, Ott J: Establishing appropriate genome-wide significance levels for canine linkage analyses. J Hered 2003, 94: I-7.

10. Guyon R, Lorentzen TD, Hitte C, Kim L, Cadieu E, Parker HG, Quignon P, Lowe JK, Renier C, Gelfenbeyn B, Vignaux F, DeFrance HB, Gloux S, Mahairas GG, Andre C, Galibert F, Ostrander EA: A I-Mb resolution radiation hybrid map of the canine genome. Proc Nat Acad Sci 2003, 100:5296-5301.

II. Schmutz SM, Berryere TG, Goldfinch AD: TYRPI and MCIR genotypes and their effects on coat color in dogs. Mam Gen 2002, I 3:380-387.

12. Cargill EJ, Clark LA, Steiner JM, Murphy KE: Multiplexing of canine microsatellite markers for whole-genome screens. Genomics 2002, 80:250-253.

13. Cargill EJ, Schnabel RD, Murphy KE: Assignment of canine MSSI microsatellite markers to chromosomes by linkage data. DNA Seq 2004, I 5:209-2I 2

14. Almasy L, Blangero J: Multipoint quantitative-trait linkage analysis in general pedigrees. Am J Hum Gen 1998, 62: I I98-I2I I

Publish with Bio Med Central and every
scientist can read your work free of charge
"BioMed Central will be the most significant development for
disseminating the results of biomedical research in our lifetime. "
Sir Paul Nurse, Cancer Research UK
Your research papers will be:
• available free of charge to the entire biomedical community
• peer reviewed and published immediately upon acceptance
- cited in PubMed and archived on PubMed Central
- yours - you keep the copyright
Submit your manuscript here:
http://www.biomedcentral.com/info/publishing_adv.asp

